\title{
SÍNDROME DE EAGLE: RELATO DE CASO TRATADO CIRURGICAMENTE POR ABORDAGEM INTRA-BUCAL
}

Guilherme STRUJAK, Maurício ROMANOWISKI, João Luiz CARLINI

Em 1937, Eagle descreveu casos de dor faríngea e cervicofacial como sendo causadas pelo alongamento do processo estilóide ou calcificação de seus ligamentos. Ele acreditava que aproximadamente $4 \%$ da população apresentavam processo estilóide alongado, e 4\% destes pacientes apresentavam sintomas. Os sintomas são atribuídos ás variações de tamanho e posição do processo estilóide, ocasionada por fibrose dos tecidos adjacentes secundária à infecção, fratura ou cirurgia na região do processo estilóide. Devido à variedade de sintomatologia, o diagnóstico torna-se difícil. O propósito desse trabalho é relatar o caso de uma paciente, que relatava dor na região da fossa amidaliana, ao movimentar a cabeça, ao deglutir e ao abrir a boca, dor essa que irradiava para região auricular, e sensação de corpo estranho na garganta. Apresentava radiograficamente alongamento bilateral dos processos estilóides. Durante a palpação da fossa amidaliana notava-se uma espícula óssea, sendo diagnosticada como portadora da síndrome de Eagle. A paciente foi tratada com estiloidectomia bilateral por abordagem cirúrgica intraoral. Aos sete dias apresentou dor ao deglutir e limitação de abertura bucal, sendo encaminhada ao otorrinolaringologista para avaliação, devido a um refluxo nasal. Aos 30 dias apresentou melhora na abertura bucal e resolução dos sintomas. A paciente ainda encontra-se em acompanhamento. 